\title{
Nelson syndrome
}

INSERM

\section{Source}

INSERM. (1999). Orphanet: an online rare disease and orphan drug data base. Nelson syndrome. ORPHA:199244

A rare, acquired, endocrine disease characterized by the triad of diffuse skin and mucosa hyperpigmentation, markedly elevated serum adrenocorticotropin (ACTH) levels and an enlarging corticotroph adenoma, which manifest following total bilateral adrenalectomy performed for the treatment of Cushing's disease. Additionally, patients may present with headaches, visual field defects, cranial nerve palsy, pituitary apoplexy, diabetes inspidus, panhypopituitarism, and, occasionally, paraovarian or paratesticular tumors. 